\title{
EARNING QUALITY AND TAX PLANNING: EVIDENCE ON INDONESIA LISTED COMPANY
}

\author{
Theresia Trisanti \\ STIE YKPN, Yogyakarta \\ Seturan Road, Yogyakarta 55281, Indonesia \\ Email: theresia@stieykpn.ac.id
}

\begin{abstract}
This study aims to determine the effect of tax planning, profit growth and firm size on earnings quality and also to test the effect of tax planning as moderating variable to influence of profit growth, size and earnings quality. It uses secondary data of Indonesian listed manufacturing companies. It shows that profit growth directly affects earnings quality and firm size does not affect earnings quality, but after being moderated by tax planning the size of the company has a significant effect on earnings quality. It adds understanding in assessing earnings quality with the influence of tax planning so that it can be used as a decision-making consideration. The more often companies do tax planning, the company will reduce the quality of earnings.
\end{abstract}

Keywords: Profit growth, company size, profit quality and tax planning.

\section{Introduction}

The capital market is one of the important components in the world economy today so that many companies use the capital market as an effort to attract investors to invest to strengthen their financial position. The capital market will be optimal if the capital market is efficient, capital market efficiency is seen from the price of securities in the relevant information available in the public, namely the financial statements. Financial reports issued by the company are information tools that reflect the condition of the company for the basis of decision making. Part of the financial statements that get much more attention is information about company profits. Profit information is considered able to describe the condition of the company and predict investment risks in decision making (Imroatussolihah, 2013; Shiri, Vaghfi, Soltani, \& Esmaeli, 2012).

Quality accounting income is accounting profit that has little or no perception disruption and can reflect actual company performance. Information published by the company will give a signal to investors in making investment decisions (Mahjoub \& Khamoussi, 2013). The signal given will give a response that will give a varied response, the strength of the response is reflected in the value of earnings response coefficient (ERC). If investors have the opinion that the information has a high level of trust, investors will respond strongly to the information. Conversely, if the investor's response is low then the information has doubtful quality (Dyreng, Jacob, Jiang, \& Müller, 2019).
Indonesia is one of the developing countries, therefore the government needs a source of revenue that is large enough to finance its expenses. Tax is one of the sources of state revenue for financing development, so the government applies tax rules through other tax laws and regulations to maximize tax revenue. For companies, tax is a burden that must be paid to the state and can reduce the company's net income. Therefore, to reduce the corporate tax burden, many companies do tax management so that matters related to tax can be managed properly, efficiently and effectively so as to provide maximum contribution to the company. One form of business carried out in tax management is tax planning (Dyreng \& Markle, 2016).

Tax planning is part of tax management and is the first step in tax management. states that tax planning is the process of organizing a taxpayer's business or a group of taxpayers so that tax, income tax and other tax liabilities are at a minimum. Tax planning is carried out through careful analysis and utilization or opportunity in the regulatory provisions made by the government or in other words tax planning is done by utilizing differences in tax rates, differences in treatment of tax objects as a basis for tax imposition (Mangonting, 1999). Basically the motivation or purpose of a company to do tax planning is to minimize the corporate tax burden that must be paid so that the company can maximize profit after tax (Wahab \& Holland, 2012; Armstrong, Blouin, \& Larcker, 2012).

This study will examine the effect of profit growth and firm size on earnings quality and tax 
planning as a moderating variable on manufacturing companies listed on the Indonesia Stock Exchange (IDX). The measurement of tax planning uses the Cash Effective Tax Rate (Cash ETR) model developed by Dyreng, Hanlon, and Maydew (2008). Dyreng et al. (2008) uses Cash ETR because it can describe tax avoidance activities and is not affected by changes in estimates such as tax assessment or protection allowances. This study uses tax planning as a moderating variable because previous research only find the direct effect on tax planning and earning quality. Therefore, this research will investigate the moderating effect of tax planning to earnings quality. Researcher use manufacturing company, because the manufacturing industry still provides the largest contribution to tax revenue. The contribution of manufacturing industry for taxes reaches 224.95 trillion Rupiah in 2017 and on 2018 the manufacturing sector reached 251.03 trillion Rupiah with a growth of $11.3 \%$ (CNN, 2018).

Several previous studies have examined the effect of earnings growth on earnings quality. However, not many have connected with tax planning, therefore this research use tax planning as a moderation so that it can see whether tax planning can strengthen or weaken the influence of profit growth on earnings quality. Based on the background, the formulation of the problem in this study are: Does profit growth, company size have affect on earnings quality? And does tax planning moderate the effect of earnings growth and firms on earnings quality?

\section{Signaling Theory}

The originator of signaling theory is Ross (1977) stating that corporate executives who have better information about the company than potential investors will be encouraged to convey company information so that the stock price increases. Signal theory should be able to reflect the relationship between current accounting data to predict future earnings changes. A good relationship between principal (employer) and ageint (company management) will continue if the principal is satisfied with the performance of the agent and the receiver of the signal can also interpret the company's signal as a positive signal.

Signaling theory states that investment expenditure provides a positive signal about the company's growth in the future, thus increasing the stock price as an indicator of the value of the company. Signal theory also explains why companies provide information on financial statements to external parties. The company as the party that knows the condition of the company so that investors give low value to the company. Therefore, in order to minimize information imbalances (information asymmetry), companies openly disclose information about the company's prospects. One way to convey a positive signal to investors is that management conducts tax planning so that the value of the company rises. Because the value of the company is considered good if the stock price tends to increase in each period (Mohd Radzi, Islam, \& Ibrahim, 2011).

Information is expected to be able to convince external parties regarding the profit presented. Especially for those who do not understand the financial statements can take advantage of financial information in measuring company prospects. For example, companies experience high profit growth, so investors will give a strong response to the company because they are considered able to provide benefits in the future. This can make outsiders believe that the profit presented is correct according to the company's performance rather than solely engineered to increase profits in order to provide a positive signal to external parties to influence decisions that will affect the increase in share ownership. Likewise with the size of the company, the larger the size of the company, the more it is known by the community, the easier it is to get information about the company.

According to Jensen and Meckling (1976) example of agency relationship is a contract where the owner (principal) authorizes management (agent) to make the best decision for the principal. Other explanation of agency theory by Herrmann and Inoue (1996) is a relationship or contract between the principal and agent where it is assumed that each individual is solely motivated by the interests of himself so that it creates a conflict of interest between the principal and agent. The relationship between principal and agent can affect the condition of information imbalance (information asymmetry) because the agent is more aware of the condition of the company compared to the principal.

Information asymmetry can encourage agents to fulfill their interests by manipulating information to suit the principal's wishes. Agency conflicts can result in the nature of management reporting profit in an opportunistic manner to maximize personal interests. Herrmann and Inoue (1996) stated that with agency theory there is a difference in reporting between commercial income and fiscal profit that can cause a conflict of interest for management in reporting company activities or performance. Management will report high profit in financial statements to obtain compensation or related to debt contract regulations. Tax planning activities can be done with an explicit 
tax reduction. Tax planning creates opportunities for agents to cover up bad information that can mislead investors. If this is done it will result in a decrease in the quality of the company's earnings.

\section{Tax Planning}

Wahab and Holland (2012) states that tax planning is a capacity that is owned by taxpayers to compile financial activities to get a minimum tax expense. Tax planning is known as an effective tax planning through tax avoidance procedures in accordance with the Tax Law. Hong and Smart (2010) states that tax planning is a structuring action that is related to the consequences of potential tax which is the pressure to control every transaction that has to do with corporate tax. The aim is to streamline the amount of tax transferred to the government through so-called tax avoidance and not tax smuggling which is a fiscal crime that cannot be tolerated. The general purpose of tax planning is to minimize the amount and total tax owed by a legal taxpayer. In addition, it is also used to meet the company's targets for the completion of tax obligations based on the correct, complete and timely tax planning method and also refers to the applicable Tax Law, so that administrative sanctions can be avoided in the form of interest, fines, tax increases or criminal sanctions. The motivation of tax planning in general to maximize profit after tax by utilizing opportunities or opportunities in the regulatory provisions made by the government to provide different treatment of tax objects as a basis for tax imposition (Feller \& Schanz, 2015).

\section{Profit Quality}

The strength of market response to earnings information is measured using earnings response coefficient (ERC). A high $E R C$ indicates reported quality earnings. According to Erickson, Hanlon, and Maydew (2004) and Kurniawati (2014) there are three things that need to be known in earnings quality: (1) the quality of earnings depends on information relevant to decision making; (2) the quality of earnings is seen from the profit figures in the financial statements whether the earnings information describes the company's financial performance; (3) the quality of earnings can be the basis for decision making.

Separation of ownership between management and owner causes conflict in the control and management of the company which results in the manager acting not according to the owner's wishes. This conflict because manager tends to want to gain profit even at the expense of the interests of the owner. However, the manager also does not want to disappoint the owner so that the manager manipulates to meet the target of the owner. The manipulated profit cannot show the actual profit, resulting in decreased profit quality.

\section{Profit Growth}

Profit growth was calculated by reducing net income this year with last year's net profit, then dividing the net income last year. Profit growth is an increase or decrease in earnings per year expressed in percentages. Profit growth affects the quality of earnings, because if the company has a chance to grow, it is considered that the performance of the company is in good condition. So, the higher the opportunity for a company to grow, the higher the quality of its profits, so that an increase in profits will be responded positively by investors (Luqman \& Shahzad, 2012; Sun \& Rath, 2008).

\section{Company Size}

According to Siregar and Utama (2008) if the size of the company gets bigger then the information provided by the company to investors can help in making investment decisions in the company. Large companies have relatively large growth opportunities compared to small companies, so the return on largescale companies is higher than the rate of return in small companies. Therefore, investors will tend to believe in large companies compared to small companies with the hope of large profits. Size of the company showed the stability of the company to carry out economic activities of the company. If the size of the company gets bigger then it can be the center of attention of the government and will lead to a tendency whether the company obeys taxes or avoids taxes. Thus, the quality of the company's financial statements must be reliable, free from profit manipulation because it can obscure the information available, especially related to shrinking the profits of the company with the aim of minimizing taxable income that makes the corporate tax paid also small (Kim \& Byun, 2010).

\section{Classification of Moderation Variables}

According to Deng et al. (2015) and Martínez, Saulo, Escobar, and Leao (2017) moderation variable is a variable that is to strengthen or weaken the influence of independent variables on the dependent variable. One characteristic of the moderating variable 
is that it is not influenced by the independent variable. In choosing a moderating variable a relationship model is based on the results of thought and theoretical or rational considerations, whether the variable allows to be used as a moderating variable or not. The benefit of giving moderation variables is to be able to specify for whom and under what conditions the relationship model can be applied. In addition, to explain the differential effect of independent variables. Moderation variables do not correlate with independent variables but interact with independent variables. Moderation variables can be classified into four types namely:

Table 1

Type of Moderation Variable

\begin{tabular}{lll}
\hline $\begin{array}{l}\text { Moderation } \\
\text { Variable }\end{array}$ & $\begin{array}{l}\text { Direct Relationship } \\
\text { (independent } \rightarrow \\
\text { dependent) }\end{array}$ & $\begin{array}{l}\text { With } \\
\text { Moderation } \\
\text { Variables }\end{array}$ \\
\hline Pure Moderator & Not significant & Significant \\
Quasi & Significant & Not \\
Moderator & & Significant \\
Prediktor & Significant & Not \\
Moderator & & significant \\
Homologister & Not significant & Significant \\
Moderator & &
\end{tabular}

Source: Martínez et al., 2017

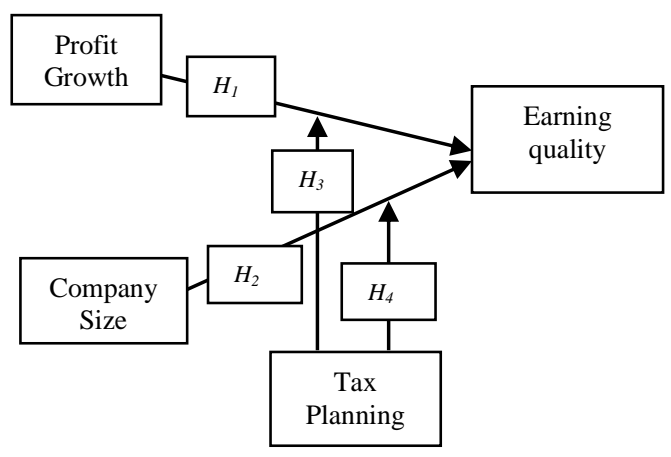

Figure 1. The conceptual research framework

\section{Effect of Profit Growth on Earnings Quality.}

Research by Gravelle (2015), Ismail and Weetman (2008) found a positive relationship between earnings growth and earnings quality. Companies with high growth rates provide high returns for investors in the future, thus encouraging management to report high profits to meet investor expectations by manipulating profits which results in lower earnings quality. Manipulation carried out by management is used to improve the assessment of company performance, thus giving the assumption that the company's performance is very good because it can increase profits every period. Some research found same result that profit growth affects the quality of earnings because if the company has a chance to grow, it is considered that the company's performance is in good condition. Investors can provide a strong response to companies that generate high profits because they are considered able to provide benefits in the future. So, the higher the chance that the company will grow and develop, the higher the profit quality will be so that an increase in profit will be responded positively by investors. Companies that have good profit growth profit growth will be candidates for investors to invest. According to Lai and Tam (2007), Tseng and Lai (2007) states that earnings growth has a significant effect on earnings quality and has a positive coefficient that shows a unidirectional relationship.Based on the description can be formulated hypotheses:

$H_{l}$ : Profit growth affects positively earnings quality.

\section{Effect of Company Size on Earnings Quality}

Some research showed that a company has a large total assets and is classified as a large-sized company that easily has access to funding sources and has a good level of financial performance, but it is not necessarily guarantee that the quality generated is high. This is because the company is relatively large as well, because the infrastructure of large companies, the costs incurred for operations are also large (Dyreng \& Markle, 2016; Zeng, 2010). Then the profits of large companies usually settle on the main posts such as inventory and merchandise so that they appear to have high profits but have not guaranteed the quality of profits generated because the profits generated are still in the form of inventory and receivables that have not been received in cash (Hassan, 2012). Other research by Klingenberg, Timberlake, Geurts, and Brown (2013) states that if the size of the company gets bigger then the information provided by the company to investors can help in making investment decisions. Size of a large company has a relatively large growth opportunity compared to a small company, so that the rate of return of shares with large company size is higher than the rate of return of small companies. Therefore, investors will tend to believe in large companies compared to small companies with the hope of large profits and other research shows that firm size has a significant effect on earnings quality and has a positive coefficient (Prasad, Rogoff, Wei, \& Kose, 2003).Based on the description can be formulated hypotheses:

$\mathrm{H}_{2}$ : Company size affects positively earning quality. 


\section{Tax Planning Moderates the Effect of Profit Growth on Earning Quality}

Earnings growth is an increase or decrease in earnings per year expressed in percentages. Profit growth affects the quality of earnings because if the company has a chance to grow, it is considered that the performance of the company is in good condition (Armstrong et al., 2012). The company experiences profit growth, so investors will give a strong response to the company because the company is considered capable of providing benefits for the future. So, the higher the profit will be responded positively by investors. Companies that have good profit growth will be strong candidates for investors (Rydqvist, Schwartz, \& Spizman, 2014).

According to Dyreng et al. (2019) states that profit growth has a significant effect on earnings quality and has a positive coefficient that shows a direct relationship. Profit growth is related to tax planning, that is if the company experiences high profit growth, then the corporate tax burden is also high, thereby reducing the company's profit and the obligation to pay high corporate taxes. Therefore, management will use various ways to achieve profit targets. Tax planning and earnings management are related to each other because both aim to achieve profit targets by engineering the company's profit numbers. If carried out by management, the published profit does not reflect actual profit and can mislead investors in decision making (Blouin, 2014; Mgammal, Bardai, \& $\mathrm{Ku}$ Ismail, 2018). Based on the description can be formulated hypotheses:

$H_{3}$ :Tax planning moderates the effect of profit growth on earnings quality.

\section{Tax Planning Moderates the Effect of Company Size on Profit Quality}

According to Siregar and Utama (2008) states that if the size of the company gets bigger then the information provided by the company to investors can help in making investment decisions. The size of a large company has a relatively large growth opportunity compared to a small company, so that the rate of return of shares with large company size is higher than the rate of return of small companies. Therefore, investors will tend to believe in large companies compared to small companies with the hope of large profits, firm size has a significant effect on earnings quality and has a positive coefficient. Firm size has a positive effect on tax avoidance. This shows that the greater the size of the company, the tax planning measured by Cash ETR will be higher, thereby reducing the level of tax avoidance. This indicates that large companies will be targeted by the government regarding tax payments, so large companies must obey taxes to maintain their reputation to remain good in the eyes of the public and the government by conducting tax planning that does not violate the applicable Tax Law (Taylor \& Richardson, 2014). Based on the description can be formulated hypotheses:

$H_{4}$ :Tax planning moderates the effect of firm size on earnings quality.

\section{Research Method}

Based on research by (Dyreng et al., 2019) profit growth is calculated by subtracting current year's net income from last year's net profit, then dividing it by net income last year. The profit growth formula is as follows:

$$
\begin{aligned}
& \text { Profit Growth } \\
& =\frac{\text { Net Profit year } t-\text { net profit year } t-1}{\text { net profit year } t-1}
\end{aligned}
$$

\section{Company Size}

According to Luqman and Shahzad (2012) company size is measured through natural logarithms of total assets. Natural logarithms are selected to flatten data or avoid vulnerable data that is too far away. Total assets are chosen by considering that asset values are relatively more stable when compared to market value and sales. The greater the logarithm of the total assets, the greater the size of the company or the company's assets. The company size formula is as follows:

Size $=\operatorname{Ln}($ Total Asset $)$

\section{Profit Quality}

$E R C$ is a response to profits announced by the company, this response reflects the earnings quality reported by the company. The proxy of the stock price is used for cumulative abnormal return $(C A R)$ while the proxy of accounting profit is unexpected earnings (EU) (Edwards, Schwab, \& Shevlin, 2016; Mohd Radzi et al., 2011). Calculation of earnings quality as follows. Stages to calculate $E R C$.

Calculate $C A R$

1. Calculate Actual Return on Investment $(R i, t)$

$R_{i, t}=\left(P_{i, t}-P_{i t-1-1}\right) /\left(P_{i b t-1}\right)$

Remarks:

$R_{i, t}=$ return that occurs for company $i$ on day $t$

$P_{i, t}=$ closing price of shares $i$ on day $t$

$P_{i, t-1}=$ closing price of shares $i$ on day $t-1$ 
2. Calculate Market Return $(R M)$

$R M_{t}=\left(\right.$ IDX $_{\text {composite }}-$ IDX composite $\left._{t-1}\right) /($ IDX compt $\left._{t-1}\right)$

Remarks:

$R M t=$ return day market $t$

IDX composite $_{t}=$ composite stock price index on day $t$

IDX composite $_{t-1}=$ closing price of shares $i$ on day $t$

3. Calculate Abnormal Return $(A R)=A R i, t=$

Rit - RMt

Remarks:

$A R_{i, t}=$ abnormal return of company $i$ on day $t$

$R_{i t}=$ real return of company $i$ on day $t$

$R M_{t}=$ market return on day $t$

Calculate the $E U$

$U E_{i t}=\left(E_{i t}-E_{i t-1}\right) /\left(E_{i t-1}\right)$

Remarks:

$U E_{i} t=$ unexpected company earnings $i$ in period $t$

$E_{i t}=$ earnings per company share $i$ in period $t$

$E_{i t-1}=$ earnings per company share $i$ in period $t-1$

Calculates ERC

CARit $=\alpha+b U E i t+\varepsilon$

Remarks:

$C A R_{i t}=$ cumulative abnormal return company $i$ in year $t$

$U E_{i t}=$ unexpected company earnings $i$ in period $t$

$\alpha=$ constant

$b=$ earnings response coefficient

$\varepsilon=$ error

\section{Tax Planning}

In this study tax planning uses by Alexander (2013), Dyreng et al. (2008) and the Cash Effective Tax Rate (Cash ETR) model developed by (Lai \& Tam, 2007)with the formula:

CASH Effective Tax Rate

$=\frac{\text { Tax Paid }}{\text { Earning Before Tax }- \text { Income }}$

For classification of moderation variables, according to Dyreng, Hoopes, and Wilde (2016) moderating variables are variables that are strengthening or weakening the influence of independent variables on the dependent variable. One characteristic of the moderating variable is not influenced by independent variables. In choosing a moderating variable a relationship model is based on the results of thought and theoretical or rational considerations, whether the variable allows to be a moderating variable or not. The benefit of giving a moderating variable is that it can specify for whom and under what conditions the relationship model can be applied. In addition, to explain the differential influence of independent variables. Moderation variables do not correlate with independent variables but interact with independent variables.

\section{Results and Discussion}

The population of this study are companies in the manufacturing industry that are listed on the Indonesia Stock Exchange (IDX) in 2015-2018 the sample selection process uses purposive sampling method and from the selection results obtained 28 companies that meet the criteria. Based on the previous sample selection process, a final sample of 28 companies was obtained during the four years of observation total are 112 observation, from Table 2 display list of sample and Table 3 is the descriptive data about sample companies.

Table 2

List of Sample

\begin{tabular}{lc}
\hline \multicolumn{1}{c}{ Description } & $\begin{array}{c}\text { Number of } \\
\text { Company }\end{array}$ \\
\hline $\begin{array}{l}\text { Manufacturing companies listed on the } \\
\text { IDX during 2015-2018 }\end{array}$ & 150 \\
Companies that did not profits during & $(51)$ \\
year 2015-2018 & \\
Report data is incomplete during 2015- & $(60)$ \\
2018 & \\
Financial statements does not use the & $(10)$ \\
rupiah currency & \\
Total sample & 28 \\
Year of observation & 4 \\
Number of samples (28 x 4 years) & 112 \\
\hline Source: Indonesia Stock Exchange, 2018
\end{tabular}

Source: Indonesia Stock Exchange, 2018

Table 3

Descriptive Statistic

\begin{tabular}{lcccc}
\hline Variable & $\begin{array}{c}\text { Mini- } \\
\text { mum }\end{array}$ & $\begin{array}{l}\text { Maxi- } \\
\text { mum }\end{array}$ & $\begin{array}{c}\text { Ave- } \\
\text { rage }\end{array}$ & $\begin{array}{c}\text { Deviation } \\
\text { Standard }\end{array}$ \\
\hline $\begin{array}{l}\text { Profit } \\
\text { Growth }\end{array}$ & 0.0826 & 52.3390 & 1.460790 & 7.7229032 \\
$\begin{array}{l}\text { Company } \\
\text { Size }\end{array}$ & 12.9969 & 29.5159 & 22.650565 & 5.568044 \\
$\begin{array}{l}\text { Profit } \\
\text { Quality }\end{array}$ & 0.0012 & 0.0509 & 0.001916 & 0.0054313 \\
Tax & 0.0075 & 12.6446 & 0.620950 & 1.4526892 \\
Planning & & & & \\
\hline
\end{tabular}

\section{Analysis Partial Least Square (PLS)}

The structural model or inner model in the conceptual framework will be calculated using the Goodness of Fit Inner Model based on the $R^{2}$ values 
for each endogenous variable namely profit growth and firm size. The Goodness of Fit Inner Model using PLS is measured by Stone-Geisser Q-Square Test in the form of $Q$-Square predictive relevance calculated based on $R^{2}$ for exogenous variables, namely earnings quality of 0.12 or $12 \%$, so that structural diversity is $12 \%$ and $88 \%$ explained other variables outside the research model. The structural model is considered fit if the $p$-value of average $R$-square (ARS) and average path coefficient $(A P C)$ is $<5 \%$ and the $A V I F$ value is $<5 \%$. If the research passes the Goodness of $F_{i t}$ Test, the research can proceed at the hypothesis testing stage. Evaluation results of the Goodness of Fit Model function serves to determine the suitability of a model used in the study (Deng et al., 2015; Shackman, 2013).

Testing the hypothesis in this study is done by examining the relationship between the variables of earnings growth, the size of the company to earnings quality and tax planning as a moderating variable. The path coefficient level in the WapPls model used in this study is $p$-value $<0.10$. If the results of the inner model test are significant ( $p$-value $\leq 0.10$ ), it means that there is a significant influence. The result of testing the hypothesis can be seen in the path diagram analyzed using PLS in Figure 2.

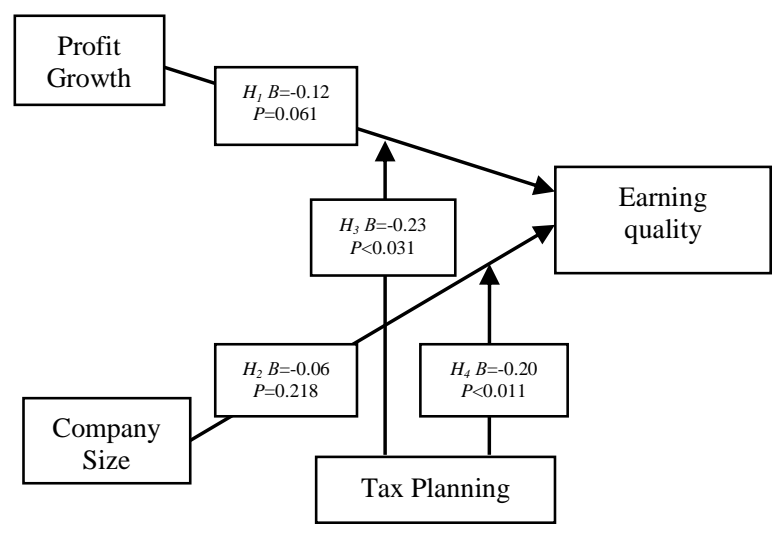

Figure 2. Hypothesis testing result

Table 4

Hypothesis Testing Results

\begin{tabular}{cccc}
\hline Hypo-thesis & $\begin{array}{c}\text { Path } \\
\text { Coefficient }\end{array}$ & P-value & Description \\
\hline$H_{1}$ & -0.12 & $0.061^{* *}$ & Supported \\
$H_{2}$ & -0.06 & 0.218 & Not Supported \\
$H_{3}$ & -0.23 & $<0.013^{*}$ & Supported \\
$H_{4}$ & -0.20 & $<0.011^{*}$ & Supported \\
\hline
\end{tabular}

** $10 \%$ significance $* 5 \%$ significance

Source: PLS process out put

Based on Table 4 we can see profit growth positively influences earnings quality this study supports the research of Luqman and Shahzad (2012) which states that profit growth positively affects earnings quality because high-growth companies provide high returns for investors in the future, that will come, thus encouraging managers to report high profits to meet investor expectations by manipulating earnings which results in lower earnings quality. Manipulation carried out by management is used with reason to improve the assessment of company performance, thus giving the assumption that the company's performance is very good because it is able to increase profits every period (Diyanty, 2014; Nawaiseh, 2016).

The size of the company has no effect on earnings quality as we see on Table 4 , this study reject the research of Hassan (2012) and Zeng (2010) which states that firm size affect earnings quality because even though the company has a large total assets and is classified as a company with a large company size, easily possessing funding source assets and having a good level of financial performance does not necessarily guarantee that the quality of the profits generated good quality. Large corporate profits usually settle in major posts such as inventory and merchandise, so that it looks to have high profits but has not guaranteed the quality of profits generated because the profit generated is still in the form of inventory and receivables that have not been received in cash.

From Table 4, tax planning moderates the influence of earnings growth on earnings quality because profit growth is related to tax planning, namely if the company experiences high profit growth, the corporate tax burden is also high, thereby reducing corporate profits and the obligation to pay high corporate taxes. Therefore, management will use various ways to achieve profit targets. However, companies that often do tax planning will result in smaller profits from companies that do not carry out tax planning, thus resulting in a decrease in the quality of profits generated by the company (Dyreng et al., 2019).

Tax planning moderates the influence of firm size on earnings quality because the larger the size of the company, the company will more easily obtain profits so that the resulting profits are greater as showed on Table 4. However, some researcher concluded the larger the size of the company is not necessarily the profit that is produced is quality because the more often companies do tax planning, then the company can reduce the quality of earnings. Companies that often do tax planning result in decreased profits due to more recognized costs so that the taxes paid are lower before tax planning (Dyreng et al., 2016). 


\section{Conclusion and Suggestions}

Based on the analysis and discussion that has been done in the previous chapter, the results of the research that has been done can be concluded that profit growth positively affects earnings quality and also the size of the company does not affect earnings quality. However, tax planning moderates the effect of earnings growth on earnings quality and the tax planning variable is Quasi Moderator for the influence of profit growth on earnings quality. Therefore, tax planning variables moderating the influence of firm size on earnings quality and the tax planning variable is the Pure Moderator for the influence of firm size on earnings quality. This study has several limitations, among others, first, this study only uses companies engaged in the manufacturing industry as samples so that it cannot be generalized to other industries besides the manufacturing industry. Secondly, manufacturing companies in Indonesia have not experienced successive profits in the research period, this has an impact on the number of sample companies used to be small. As a suggestion for further research, it should expand the research sample not only the manufacturing industry but all industrial sectors, so that the results of the research can be more meaningful by providing evidence of earning quality of each industry sector.

\section{References}

Alexander, R. M. (2013). Tax transparency. Business Horizons, 56(5), 543-549.

Armstrong, C. S., Blouin, J. L., \& Larcker, D. F. (2012). The incentives for tax planning. Journal of Accounting and Economics, 53(1-2), 391411.

Blouin, J. (2014). Defning and measuring tax planning aggressiveness. National Tax Journal, 67(4), 875-900.

CNN. (2018). Kontribusi pajak industri manufaktur tahun 2018. Retrieved from www. Cnnindonesia.com

Deng, B. C., Yun, Y. H., Liang, Y. Z., Cao, D. S., Xu, Q. S., Yi, L. Z., \& Huang, X. (2015). A new strategy to prevent over-fitting in partial least squares models based on model population analysis. Analytica Chimica Acta, 880, 32-41.

Diyanty, V. (2014). Earning quality, family controlling ownership and the role of corporate governance. A paper presented in the Simposium Nasional Akuntansi 17 Mataram, Lombok.

Dyreng, S. D., Hanlon, M., \& Maydew, E. L. (2008). Long-run corporate tax avoidance. The Accounting Review, 83(1), 61-82.
Dyreng, S. D., Hoopes, J. L., \& Wilde, J. H. (2016). Public pressure and corporate tax behavior. Journal of Accounting Research, 54(1), 147186.

Dyreng, S. D., Jacob, M., Jiang, X., \& Müller, M. A. (2019). Tax Incidence and Tax Avoidance. Retrieved from https://ssrn.com/ abstract=3070239

Dyreng, S. D., \& Markle, K. S. (2016). The effect of financial constraints on income shifting by U.S. multinationals. The Accounting Review, 91(6), 1601-1627.

Edwards, A., Schwab, C., \& Shevlin, T. (2016). Financial constraints and cash tax savings. The Accounting Review, 91(3), 859-881.

Erickson, M., Hanlon, M., \& Maydew, E. L. (2004). How much will firms pay for earnings that do not exist? Evidence of taxes paid on allegedly fraudulent earnings how much will firms pay for earnings evidence of taxes paid on allegedly fraudulent earnings. The Accounting Review, 79(2), 387-408.

Feller, A., \& Schanz, D. (2015). The three hurdles of tax planning: How business context, aims of tax planning, and tax manager power affect tax expense. Arqus Discussion Paper No. 176. Retrived from https://doi.org/10.2139/ssrn.2512177.

Gravelle, J. G. (2015). Tax havens: International tax avoidance and evasion. Washington, DC: Congressional Research Service.

Hassan, S. U., \& Ahmed, A. (2012). Corporate governance, earnings management and financial performance: A case of Nigerian manufacturing firms. American International Journal of Contemporary Research, 6(7), 214-226.

Herrmann, D., \& Inoue, T. (1996). Income smoothing and incentives by operating condition: An empirical test using depreciation change in Japan. Journal of International Accounting, Auditing and Taxation, 5(2), 161-177.

Hong, Q., \& Smart, M. (2010). In praise of tax havens: International tax planning and foreign direct investment. European Economic Review, 54(1), 82-95.

Imroatussolihah, E. (2013). Pengaruh risiko, leverage, peluang pertumbuhan, persistensi laba dan kualitas tanggung jawab sosial perusahaan terhadap earning response coefficient pada perusahaan high profile. Jurnal Ilmiah Manajemen, 1(1), $75-87$.

Indonesia Stock Exchange. (2018). IDX. Retrieve from https://www. idx.co.id/en-us/ products/idxdata-service s/

Ismail, N., \& Weetman, P. (2008). Regulatory profit targets and earnings management in initial public offerings: The case of Malaysia. Journal of Financial Reporting and Accounting, 6(1), 91-115. 
Jensen, M. C., \& Meckling, W. H. (1976). Theory of the firm: Managerial behavior, agency costs and ownership structure. Journal of Financial Economics, 3(4), 305-360.

Kim, K., \& Byun, J. (2010). Effect of investor sentiment on market response to stock split announcement. Asia-Pacific Journal of Financial Studies, 39(6), 687-719.

Klingenberg, B., Timberlake, R., Geurts, T. G., \& Brown, R. J. (2013). The relationship of operational innovation and financial performance - A critical perspective. International Journal of Production Economics, 142(2), 317-323.

Kurniawati，A. D. (2014). Pengaruh karakteristik perusahaan terhadap earnings response coefficient. Jurnal Akuntansi Bisnis, 13(25), 1-24.

Lai, L., \& Tam, H. (2007). Independent directors and the propensity to smooth earnings: A study of corporate governance in China. The Business Review, Cambridge, 7(1), 328-335.

Luqman, R. A., \& Shahzad, F. (2012). An association between income smoothing, income tax and profitability ratios in Karachi Stock Exchange (An empirical investigation). Interdiciplinary Journal of Contemporary Research in Business, 3 (9), 986-990.

Mahjoub, L. B., \& Khamoussi, H. (2013). Environmental and Social Policy and Earning Persistence. Business Strategy and the Environment, 22(3), 159-172.

Mangonting, Y. (1999). Tax planning: Sebuah pengantar sebagai alternatif meminimalkan pajak. Jurnal Akuntansi Keuangan, 1(1), 43-53.

Martínez, J. L., Saulo, H., Escobar, H. B., \& Leao, J. (2017). A new model selection criterion for partial least squares regression. Chemometrics and Intelligent Laboratory Systems, 169, 64-78.

Mgammal, M. H., Bardai, B., \& Ku Ismail, K. N. I. (2018). Corporate governance and tax disclosure phenomenon in the Malaysian listed companies. Corporate Governance, 18(5), 779-808

Mohd Radzi, S. N. J., Islam, M. A., \& Ibrahim, S. (2011). Earning quality in public listed companies: A study on malaysia exchange for securities dealing and automated quotation. International Journal of Economics and Finance, 3(2), 233-244.
Nawaiseh, M. E. (2016). Impact of external audit quality on earnings management by banking firms: Evidence from Jordan. British Journal of Applied Science \& Technology, 12(2), 1-14.

Prasad, E. S., Rogoff, K., Wei, S.-J., \& Kose, M. A. (2003). Effects of financial globalization on developing countries: Some empirical evidence. Washington, DC: International Monetary Fund, Retrieved from http://www.nber.org/ wei/data/ prw k2003/prwk2003.pdf

Ross, S. A. (1977). The determination of financial structure: The incentive-signalling approach. The Bell Journal of Economics, 8(1), 23-40.

Rydqvist, K., Schwartz, S. T., \& Spizman, J. D. (2014). The tax benefit of income smoothing. Journal of Banking and Finance, 38, 78-88.

Shackman, J. D. (2013). The use of partial least squares path modeling and generalized structured component analysis in international business research: A literature review. International Journal of Management, 30(3-1), 78-85.

Shiri, M. M., Vaghfi, S. H., Soltani, J., \& Esmaeli, M. (2012). Corporate governance and earning quality: Evidence from Iran. Middle-East Journal of Scientific Research, 11(6), 702-708.

Siregar, S. V., \& Utama, S. (2008). Type of earnings management and the effect of ownership structure, firm size, and corporate-governance practices: Evidence from Indonesia. International Journal of Accounting, 43(1), 1-27.

Sun, L., \& Rath, S. (2008). Fundamental determinants, opportunistic behavior and signaling mechanism: An integration of earnings management perspectives. International Review of Business Research Papers, 4(4), 406-420.

Taylor, G., \& Richardson, G. (2014). Incentives for corporate tax planning and reporting: Empirical evidence from Australia. Journal of Contemporary Accounting and Economics, 10(1), 1-15.

Tseng, L.-J., \& Lai, C.-W. (2007). The relationship between income smoothing and company profitability: An empirical study. International Journal of Management, 24(4), 727-733.

Wahab, N. S. A., \& Holland, K. (2012). Tax planning, corporate governance and equity value. British Accounting Review, 44 (2), 111-124.

Zeng, T. (2010). Income tax liability for large corporations in China: 1998-2007. Asian Review of Accounting, 18(3), 180-196. 